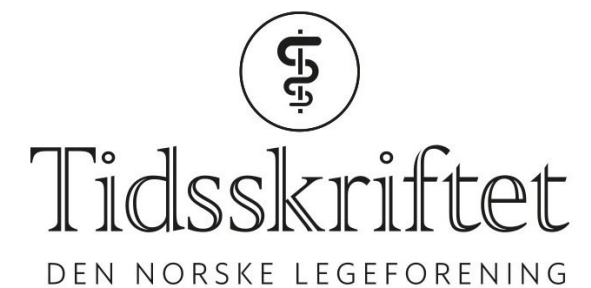

DEN NORSKE LEGEFORENING

\title{
Hva vet vi om langtidsvirkninger av antipsykotika?
}

DEBATT

\section{GEIR SMEDSLUND}

E-post: geir.smedslund@fhi.no

Geir Smedslund er dr.philos, psykolog og jobber som forsker med systematiske oversikter ved Område for helsetjenester i Folkehelseinstituttet.

Forfatter har fylt ut ICMJE-skjemaet og oppgir ingen interessekonflikter.

\section{CAMILLA STOLTENBERG}

Camilla Stoltenberg er direktør ved Folkehelseinstituttet og professor ved Universitetet i Bergen. Forfatter har fylt ut ICMJE-skjemaet og oppgir ingen interessekonflikter.

Langtidsvirkningene av antipsykotika er ukjente. Bedre helseregistre kan gi ny kunnskap.

Folkehelseinstituttet har på oppdrag fra Vestre Viken utarbeidet en kunnskapsoppsummering om effekt og bivirkninger ved langtidsbehandling med antipsykotika (1). Den nasjonale retningslinjen åpner for vedlikeholdsbehandling med antipsykotika ut over to år (2), og vi har forsøkt å klarlegge hva man vet om effekten av slik behandling for pasienter med schizofrenispektrumdiagnoser.

Vi søkte i ni elektroniske databaser etter systematiske oversikter om effekter av bruk av antipsykotika i to år eller lenger hos personer med schizofrenispektrumdiagnoser. Søk etter primærstudier ga 12640 treff. Vi inkluderte åtte publikasjoner basert på tre pasientutvalg. Det lave antallet skyldes at de fleste studiene er for kortvarige. Inkluderte studier er kvalitetsvurdert med sjekkliste, og vår tillit til resultatene er vurdert ved hjelp av GRADE (Grading of Recommendations Assessment, Development and Evaluation)(3).

\section{Hva fant vi?}

De inkluderte studiene var fra Finland, Sverige og USA. I studiene fra finske og svenske helseregistre var mortaliteten etter bruk av antipsykotika i mer enn to år lavere enn hos pasienter som ikke hadde brukt antipsykotika, men de absolutte forskjellene var små, og vi kunne ikke fastslå en årsakssammenheng. I en studie fra Chicago med 20 års oppfølgingstid fungerte pasienter uten antipsykotika bedre arbeidsmessig enn pasienter som hadde brukt antipsykotika i mer enn to år. Pasienter uten antipsykotika hadde sjeldnere såkalte positive og negative symptomer. Risiko for rehospitalisering varierte med legemiddel, og tallene var usikre. Heller ikke her kunne vi fastslå om det var årsakssammenheng. Resultater for utfall som parkinsonisme og metabolske forstyrrelser manglet i de inkluderte studiene. Fordi vi bare kunne inkludere observasjonsstudier med risiko for systematiske skjevheter, graderte vi alle resultatene til «svært lav tillit». Med andre ord vet vi ikke hvilke effekter og 
bivirkninger behandling med antipsykotika i mer enn to år har for pasientene sammenlignet med ingen bruk.

\section{Hvorfor er ikke konklusjonene klarere?}

For å svare må vi tilbake til den gangen de første antipsykotika ble utviklet for omtrent 60 år siden. Troen på disse legemidlene var da så stor at det ikke ble utført en eneste randomisert studie der en gruppe pasienter ikke brukte antipsykotika. Det finnes fremdeles ingen slike studier (4). Da antipsykotika ble innført, ble de gitt til alle pasienter. I dag er det ansett som uetisk å ikke gi pasienter disse legemidlene. Derfor rekrutterer de randomiserte studiene pasienter som allerede har hatt nytte av antipsykotika. Deretter blir halvparten randomisert til å fortsette med antipsykotika mens den andre halvparten skal slutte eller trappe ned. Hvis man slutter brått med antipsykotika, er faren for tilbakefall stor (5). Det er vanskelig å fastslå for den enkelte pasient hvorvidt tilbakefallet skyldes abstinens og hva som skyldes bortfall av en mulig beskyttende effekt av antipsykotika (6). Vi fant ingen randomiserte kontrollerte studier hvor den reelle behandlingstiden oversteg to år (1). Registerstudiene fra Sverige og Danmark kunne ikke fastslå årsakssammenheng mellom bruk av antipsykotika og mortalitet. Den lille studien fra Chicago som fulgte pasientene over 20 år kunne heller ikke fastslå årsaksforhold mellom arbeidsfungering og langtidsbruk av antipsykotika. Det kan være at pasienter som får legemidlene over lang tid i utgangspunktet er ulike de som ikke får dem.

\section{Behov for direkte personidentifiserbart legemiddelregister}

Randomisering av pasienter til å bruke eller ikke bruke antipsykotika i flere år er neppe realistisk. Vi må bruke observasjonsstudier. Kohortstudier og rene medisinske kvalitetsregistre har svakheter fordi det ikke er tilfeldig hvem som blir med eller faller fra underveis. Frafallet kan være stort. Nasjonale obligatoriske helseregistre har ikke frafall og kan inkludere nødvendige opplysninger. Problemet er at helseregistrene ikke alene kan svare på spørsmål om langtidseffekter og bivirkninger av legemidler. Registrene i Sverige og Finland har informasjon om diagnose og uthenting av resepter slik at man kan beregne kumulativ bruk. Men de mangler informasjon som kan predikere beslutninger om medisinering, som alvorlighetsgrad av sykdommen.

Vi har ikke pålitelig kunnskap om langtidsvirkninger av antipsykotika i dag. Videre utvikling av eksisterende nasjonale helseregistre er avgjørende for å oppnå dette. Et direkte personidentifiserbart legemiddelregister med opplysninger om all legemiddelbruk på individnivå må etableres, og de eksisterende Norsk pasientregister, Kommunalt pasient- og brukerregister og Dødsårsaksregisteret må videreutvikles. Slike forbedrede registre vil kunne brukes til å styrke kunnskapsgrunnlaget for pasienter med schizofrenispektrumdiagnoser. Et forbedret legemiddelregister vil i tillegg komme alle andre pasientgrupper til gode.

LITTERATUR:

1. Smedslund G, Siqveland J, Kirkehei I et al. Langtidsbehandling med antipsykotika hos personer med schizofrenispektrumlidelser: en systematisk oversikt. Oslo: Folkehelseinstituttet, 2018.

https://www.fhi.no/globalassets/dokumenterfiler/rapporter/2018/langtidsbehandling-antipsykotika-s chizofrenispektrum-rapport-2018.pdf(24.9.2018).

2. Nasjonal faglig retningslinje for utredning, behandling og oppfølging av personer med psykoselidelser. IS-1957. Oslo: Helsedirektoratet, 2013.

https://helsedirektoratet.no/Lists/Publikasjoner/Attachments/326/Nasjonal-faglig-retningslinje-for-utr edning-behandling-og-oppfolging-av-personer-med-psykoselidelser-IS-1957.pdf (24.9.2018).

3. Guyatt GH, Oxman AD, Vist GE et al. GRADE: an emerging consensus on rating quality of evidence and strength of recommendations. BMJ 2008; 336: 924 - 6. [PubMed][CrossRef] 
4. Goff DC, Falkai P, Fleischhacker WW et al. The long-term effects of antipsychotic medication on clinical course in schizophrenia. Am J Psychiatry 2017; 174: 840 - 9. [PubMed][CrossRef]

5. Hui CLM, Honer WG, Lee EHM et al. Long-term effects of discontinuation from antipsychotic maintenance following first-episode schizophrenia and related disorders: a 1o year follow-up of a randomised, double-blind trial. Lancet Psychiatry 2018; 5: 432 - 42. [PubMed][CrossRef]

6. Gøtzsche PC, Young AH, Crace J. Does long term use of psychiatric drugs cause more harm than good? BMJ 2015; 350: h2435. [PubMed][CrossRef]

Publisert: 15. oktober 2018. Tidsskr Nor Legeforen. DOI:10.4045/tidsskr.18.0729

Mottatt 20.9.2018, godkjent 24.9.2018.

(C) Tidsskrift for Den norske legeforening 2020. Lastet ned fra tidsskriftet.no 